\title{
Strukturalistická stopa Olgy Srbové ${ }^{1}$
}

\author{
Eva Stehlíková
}

Dne 17. července 2014 uplynulo plných sto let od chvíle, kdy se v Poličce narodila Olga Srbová, nadějná divadelní kritička, jejíž jméno upadlo téměř v zapomenutí. ${ }^{2}$ Máme sice k dispozici velmi seriózní heslo, které zpracovala pro Lexikon české literatury Stanislava Mazáčová (MAZAČOVÁ 2008), ale skutečnost, že Olga Srbová po svém sňatku s hercem Jaromírem Spalem³ přestala postupně používat své dívčí příjmení, způsobila, že zůstala v obecném povědomí především ta část její životní dráhy, jež byla spjata s jejím poválečným osudem, a tím i s rozhlasem. První etapa její kariéry (a celoživotní láska) je však spojena s divadlem.

Dostalo se jí dobrého vzdělání. Už v rodinném prostředí, jemuž vévodil její otec, hudební pedagog, publicista a skladatel Antonín Srba (1881-1961), nabývala širokého kulturního rozhledu. Absolvovala dívčí reálné gymnázium E. Krásnohorské v Praze, jež bylo následníkem proslulé Minervy. Studovala od roku 1933 na Filozofické fakultě Univerzity Karlovy češtinu a francouzštinu, v roce 1937 získala doktorát na základě práce Vlastnosti nového historického románu českého. Její index prozrazuje, že mezi její učitele patřili mimo jiné Jan Mukařovský, Albert Pražák, František Xaver Šalda, Miloš Weingart a Václav Tille. Ten ji nepochybně ovlivnil mimo jiné svým pojetím kritiky, stejně jako F. X. Šalda, kterému se bezmezně obdivovala celý život. Velký význam pro ni mělo inspirující prostředí Studentského časopisu, který vycházel mezi léty 1922-1942 a byl v meziválečné době tribunou středoškolské mládeže. Přispívala sem od roku 1927, byla členkou redakční rady, spolupracovala zde s Josefem Trägrem, Hanušem Bonnem, Jiřím Valjou,

\footnotetext{
1 Studie vznikla jako výstup grantového projektu „Český divadelní strukturalismus: souvislosti a potenciál“ (2011-2015, GAČR P409/11/1082). Autorka děkuje manželům Jiřímu a Sabině Langerovým, kteří jî umožnili nahlédnout do pozůstalosti Olgy Srbové-Spalové (1914-1987), uložené v jejich rodinném archivu v Jindřichově Hradci. Rukopisné paměti opsala Sabina Langerová.

2 Ve Schůzkách s literaturou na ni vzpomněla 13. 7. 2014 stanice Vltava v pořadu Krásné jiskření Olgy Spalové, který připravil Jiří Langer a režíroval Luboš Konír. K témuž výročí viz též (STEHLÍKOVÁ 2015).

3 Jaromír Spal (18. 7. 1916 - 22. 3. 1981) viz http://www.csfd.cz/tvurce/26337-jaromir-spal/. Popis absurdní situace jeho odchodu z Národního divadla, ke kterému došlo poté, co J. Spal a V. Voska žádali o snížení počtu povinných představení kvůli své třítýdenní nepřítomnosti v divadle, nebở byli na vojenském cvičení (viz BOKOVÁ 1999: 45-46).
} 
Janem Kopeckým, Pavlem Schönfeldem alias Pavlem Tigridem a dalšími. ${ }^{4}$ Lákal ji svět pražské bohémy (mezi její přátele patřila mimo jiné femme fatale avantgardy Jarmila Svatá i někdejší spolužačka Ljuba Hermanová) i lidé z okruhu intelektuální společnosti Pražského lingvistického kroužku. ${ }^{5}$ Profesionální dráha odvedla Olgu Srbovou od dalšího studia ${ }^{6}$ a posléze i od divadelní kritiky.

K rezignaci na dráhu divadelní kritičky nebyla Olga Srbová kupodivu přivedena žádnými vnějšími okolnostmi, ale svou mimořádnou zodpovědností. Poté, co se roku 1946 provdala za herce Jaromíra Spala, usoudila, že by se nutně dostala do střetu zájmů, a přestala divadelní kritiky psát. Ovšem i její život (stejně jako mnoho jiných) byl negativně ovlivněn novými poměry. Očistná komise Syndikátu českých spisovatelů jí udělila v souladu se zákonem Prozatimního Národního shromáždění o přezkoumání činnosti uměleckých a vědeckých pracovníků v době zvýšeného ohrožení republiky „nejmírnější trest“ - důtku (JANOUŠEK 2007: 38). Sama tuto situaci hořce komentuje: „Dnes je tu i taková velmi vítaná zbraň, jakou je nařčení z národní nespolehlivosti - a tak se dočkáte toho, že někdo, jehož uměleckou vzestupnou dráhu jste za protektorátu sledovali, vám vyčte, že jste to dělali, a tak byli jaksi kolaboranty." (SRBOVÁ 1945c: 6) Situace se však brzy zvrátila ve prospěch Srbové, jak je patrné z literatury (BAUER 2003: 35, 57, 65, 292, 983). Později byla ale Spalová vyšetřována pro podezření z ilegální činnosti, ${ }^{7}$ a dokonce držena ve vyšetřovací vazbě. ${ }^{8}$

Není náhodou, že byla v roce 1951 Olga Spalová donucena opustit svou kariéru středoškolské profesorky. Byla pak zaměstnána v Státním pedagogickém nakladatelství jako redaktorka Učitelských novin. Nikdy nebyla persona grata, i když jí režim posléze dovolil pracovat v Československém rozhlase, kde byla mimořádně úspěšná.

4 Charakteristiku profilu časopisu viz (RAMBOUSEK 2011): „Časopis dbal o svou nestrannost, nebyl katolický jako pozdější Jitro, ani vysloveně levicový, jeho linie byla linií Masarykovy a Benešovy republiky. [...] Časopisu postupně vtiskly svůj ráz dvě literární generace, nejprve ta teigovská, avantgardní, a pak ve třicátých letech autoři generace válečné, nejčastěji označované podle nejvýraznějšího básnického představitele jako Ortenova. [...] Na stránkách Studentského časopisu nalézáme za léta jeho existence první publikované práce desítek významných autorů a umělců.“

5 Její účast je zaznamenána na čtyřech přednáškách v roce 1936, její jméno se vyskytuje v Seznamu členů a hostů, kteří jsou zváni na přednášky i v době válečné. Viz (ČERMÁK, POETA a ČERMÁK 2012: 205, 208, 210, 219, 385-386).

6 Olga Srbová v r. 1937 nastoupila učitelskou dráhu - působila nejprve jako profesorka češtiny na reálném gymnáziu na Žižkově (1937-1938), poté v Křemencové ulici (1939-1940), v dívčím reálném gymnáziu Krásnohorská (1940-1945), po válce pracovala v gymnáziu ve Štěpánské, kde vyučovala nejen češtinu, ale i ruštinu (1945-1952). Mimo to vyučovala za okupace externě českou literaturu na dramatickém oddělení pražské konzervatoře.

7 V pozůstalosti je také zachován výmluvný lístek Oblastní úřadovna státní bezpečnosti, potvrzení o domovní prohlídce 24. 3. 1949 podezření z ileg. činnosti, zabaveny různé písemnosti, svědek J. Spal. Možná se k této události vztahuje i pár vět v nepublikovaných pamětech na s. 56: „Bojím se každého zveřejnění čehokoli. Snad od těch článků, za něž mě honili a z nichž jsem jeden vůbec nenapsala (proti jednotné škole, ačkoli s ním souhlasím).“

8 V diáři 19. 10. 1977, kdy v ní právě probíhající proces s Otou Ornestem (s nímž byli Spalovi pochopitelně v kontaktu), Jiřím Ledererem (který navíc bydlel se Spalovými ve stejném domě) a Františkem Pavlíčkem vyvolal vzpomínky na její někdejší zkušenosti se Státní bezpečností, píše: „Copak jsem taky nebyla ,zadržena“ pro nic za nic skoro měsíc." 


\title{
1.
}

Na počátku své kariéry přemýšlela Olga Srbová o tom, že se bude věnovat divadelní teorii, jak svědčí zápis v jejích rukopisných pamětech z 14. 2. 1972, v němž komentuje smrt Jana Mukařovského a střízlivě naráží na své nerealizované ambice:

\begin{abstract}
Nevím, v kolik dnes byl pohřeb Mukařovského, ale jistě jsem ho dobře uctila, když jsem si četla, co napsal Šalda o jeho „Vznešenosti přírody“. On však už nemohl ze sebe později vydat víc, musil předsedat Obráncům míru, atd. atd. Jistě bystře a dekorativně, ale kolik rozborů tu mohlo být v době odsuzující strukturalismus, co jsme se mohli naučit. Takové osobnosti jsou jediné štěstí a pýcha malého národa - nebo jediné štěstí staré pensistky, která kdysi chtěla zasvětit život tomu, co oni [podtrhla ES]. ${ }^{9}$
\end{abstract}

V díle Olgy Srbové nenalezneme mnoho teoretických prací týkajících se divadla, pokud ano, jsou vždy důkazem suverénního ovládnutí metod jejích učitelů. Spíše než o vlivu strukturalistických teorií ovšem v tomto případě můžeme mluvit o jakési strukturalistické stopě, protože, jak uvidíme, explicitní citace nebo použití strukturalistických termínů tu není přiliš časté, přesto však je zřetelné, že východisko zůstává společné. Postava v novém dramatu, otištěná ve Slovu a slovesnosti, prestižním časopise (Viz SRBOVÁ 1937c: 221-226), založeném v roce 1935 členy Pražského lingvistického kroužku, s nímž spolupracovali také mnozí čeští spisovatelé, je příspěvkem k proměně herecké postavy v soudobém divadle. Nezabývá se příliš historií (na rozdíl od Jindřicha Honzla, který ve svých úvahách pracuje vcelku konvenčně s historickým materiálem) (HONZL 1939: 239-245), ale soustřed’uje svou pozornost na texty, které jsou používány avantgardními tvůrci. Už to spojuje autorku se soudobými kulturními trendy. Není, myslím, v českém prostředí jiná doba, kdy si tvůrci a teoretici jsou tak blízko a vzájemně se ovlivňují..$^{10}$ Olga Srbová sleduje avantgardu od samých začátků své kritické tvorby ${ }^{11}$ a pochopitelně považuje Osvobozené divadlo a Burianovo D, tato „mladá divadla“ za „divadla mladých“ (SRBOVÁ 1933c: 78-79). ${ }^{12}$ Není tedy náhodou, že svůj výklad jevištního

9 Viz rukopisné paměti Olgy Srbové uložené v pozůstalosti spravované manžely Langrovými (viz pozn. č. 1).

10 Jak mne upozornila V. Ambros, signifikantní je Nezvalovo vyjádření v Dopisu J. Mukařovskému, původně vydaném ve sbírce Zpáteční lístek (1933): „Náš krok jde ruku v ruce s vědci / Básnictví netvoří už světci / A dnes už ani světáci / Příteli přijd’ dnes po práci / A vylož básníkům a včelám / Co je to med a jak to dělám.“ (NEZVAL 1981: 580)

11 Olga Srbová sleduje avantgardní divadlo od r. 1932. Kromě kritik jednotlivých představení jsou tu záhy úvahy nad programy těchto divadel. Viz její příspěvky „D 34“ (SRBOVÁ 1933b: 40-41); „D 35“ (SRBOVÁ 1935a: 190-191); „Osvobozené divadlo“ (SRBOVÁ 1934d: 88-89); „Deset let Osvobozených“ (SRBOVÁ 1937d: 262-263) i první hodnocení a polemiky viz např. „Smrt divadelní avantgardy“ (SRBOVÁ 1934e: 139140); „Deset let divadelní avantgardy“ (SRBOVÁ 1935f: 277-278). Její obdiv však ani v nejmenším neztrácí kritický osten, jak vidíme např. na jejích úvahách o Burianově inscenaci Lakomce (SRBOVÁ 1934b: 196-197), kritickém postoji k Burianově inscenaci Kupce benátského (SRBOVÁ 1934a: 266) nebo ve velmi ostré polemice s Burianovou studií Pojd'te, lidé, na divadla s železnýma kladivama (SRBOVÁ 1940a: 108).

Viz též (S. A. 1934: 45-46) (o inscenacích Jegora Bulyčova a Kata a blázna). 
znaku demonstruje na významotvorném užití koudele v Burianově Máji.$^{13}$ Stejný proces (spojení dvou plánů, v nichž předmět na jedné straně představuje sám sebe - tedy pouhou koudel použitou např. v paruce, na druhé straně představuje jiný znak - korunu stromu) shledává Srbová v novém pojetí herce a způsobu, jakým představuje osobu dramatu. Na příkladu postav z inscenace uvedené v Osvobozeném divadle ukazuje, jak se mísí plán fabule hry s plánem divákovy zkušenosti. Na základě studia textů užitých Emilem Františkem Burianem dovozuje, že struktura postavy může být zakódována už v předloze, která podtrhuje její umělost; takže to, čemu se v realistickém divadle ř́́kalo charakter, se postupně ztrácí, ustupuje psychologické vytváření postavy a postava hry se mění v jevištní postavu, která navíc existuje v několika sémantických plánech. Tu činí proměnlivou nejen literární složka divadelního artefaktu, ale i režisérovy další akce, jako je použití světla nebo umístění postavy v prostoru.

Je zřejmé, že Olga Srbová má tendenci překračovat dramatický text směrem k jeho jevištní realizaci a vidět vzájemné ovlivňování těchto sfér. V článku „Scénické poznámky autorů“ (SRBOVÁ 1937d: 98) překvapivě zkoumá, jak jsou scénické poznámky A. Dvořáka a F. Zavřela formovány soudobou divadelní praxí a jejich vztahem ke kvapilovské a hilarovské scéně. Tato zcela ojedinělá pozorování, k nimž se bohužel už nevrátila, otevírají další otázky po specifické úloze didaskalií v dramatu (knižním i neknižním, jak ř́ká).

Jistý nadhled nad materiálem a současně představa divadelního dění jako dynamické proměny jednotlivých divadelních složek a postupné změny funkce ji vede už roku 1935 ke konstatování, že je třeba nové avantgardy, protože „Osvobozené divadlo dosáhlo stabilního tvaru, který se podstatně neliší od starého divadla. Umění E. F. Buriana vyzrálo ve vlastní styl, vyrostlý z kvašení divadelní avantgardy téměř před deseti lety“ (SRBOVÁ 1934e: 139-140).

Zcela věcně popisuje i v článku „Na přelomu slohů“ (SRBOVÁ 1942a: 120-121) zásadní proměnu divadla na počátku čtyřicátých let (aniž samozřejmě může verbalizovat vnější okolnosti, které k ní vedly):

Divadlo, které se léta soustřed’ovalo na prostředky, které jen jemu byly vlastní - sázelo na situace, obraz, barvu a tvar, zvukový efekt, vědomě zatlačovalo do pozadí sdělovací funkci. Chtělo být především odpoutáno od iluze skutečnosti a osvobozeno od nadvlády literatury. Ve čtyřicátých letech už nestačí čisté umění, radost z tvaru, z prostého prožitku. Člověk už nehledá v umění stupňování životního pocitu, hledá v něm opět základní otázky svého bytí vůbec.

Jak divadlo, tak film a rozhlas se opět napájejí ze stejného zdroje, kterým je literatura. Současně film a rozhlas mění divadelní herectví, které vedou k velké citlivosti v mimice a zacházení s hlasem, k realistickému výrazu a zpřesnění psychologické kresby - „herec už není ekvilibrista slov a pohybů, není to zpěvák a tanečník, po kterém toužila avantgarda, je představitelem lidství v jeho nesčetných tvářnostech a proměnách.“

Blíže viz (SRBA 2004). 
To ovšem v žádném případě neznamená, že dědictví avantgardy bylo zapomenuto. Avantgarda zásadně ovlivnila divadelní projev svou bezprostředností, svým patosem i uměním zkratky a koncentrace, stejně jako tvorbu divadelního prostoru, kde nyní výtvarníci hledají, jak skloubit čistý tvar a divadelně účinně řešený jevištní prostor s atmosférou básníkova díla.

Není divu, že se Olga Srbová už od počátku věnovala tehdy novým médiím - filmu (stejně tak jako jím byl fascinován Roman Jakobson a Jan Mukařovský) a rozhlasu (který miloval Václav Tille). Její vztah k filmu, o němž poprvé psala jako šestnáctiletá, ${ }^{14}$ byl vcelku pragmatický. Zato k rozhlasu měla vztah velmi intimní. ${ }^{15}$ Přestože se jeho kmenovou zaměstnankyní stala až v roce 1959 (a s malým přerušením zůstala v této instituci až do svého penzionování roku 1971) a v této etapě se proslavila velmi úspěšnými pořady, které byly později vydány v knižní verzi ${ }^{16}$ zajímavé jsou hlavně počátky její externí spolupráce s rozhlasem. Zahájila je patrně prezentací svých úvah, které pak otiskovala ve Studentském časopise. ${ }^{17}$ Záhy však začala o specifice rozhlasu nejen uvažovat, ale ověřovala si ji i v praxi - upravovala pro rozhlas literární i dramatické texty (Máchovu Marinku 1937, Shakespearova Hamleta 1941), psala libreta (Probuzená fotografie 1939, Dostavenícko 1940), připravovala nejrůznější pásma (mj. Slavné monology s ukázkami ze světové dramatiky 1944) a postupně spolupracovala s rozhlasem i jako členka odborných komisí a porot.

Tuto fázi jejího zájmu o rozhlas korunuje malá brožurka Rozhlas a slovesnost (SRBOVÁ 1941), na kterou reagovalo i Slovo a slovesnost (Mts 1941: 106a) a která je dosud hodnocena jako jedna z nejvýznamnějších prací té doby (vedle Rozhlasového uměni Františka Kožíka z roku 1940 a Od rozhlasové hry $k$ rozhlasovému dramatu Miloslava Havla z roku 1942) (SLADKÝ 2002: 8: 64-65). Rozhlas se podle Olgy Srbové liší od divadla v jednom podstatném aspektu: „Divadlo je umění lidské a bude existovat, dokud budou lidé divadlo hrát. Rozhlasové umění je umění techniky a bude trvat tak dlouho, dokud nebude technika zdokonalena" (SRBOVÁ 1941: 6). Nehodlá se sice zabývat výhledy do budoucnosti, ale předpokládá (tak jako jiní autoři v té době), že se (možná) dožije „rozšíření televize, která z rozhlasu vyroste, jako vyrostl zvukový film z filmu němého“ (SRBOVÁ 1941: 6).

Zkoumá tedy soudobé možnosti rozhlasu a samozřejmě si klade základní otázky. Existuje samostatné rozhlasové umění? Je rozhlas jen technikou nebo si tato technika vynucuje nové umělecké formy? Zajímá ji především funkce rozhlasu. Chápe jeho informační funkci (dokonce ji vnímá jako možnou orální konkurenci novinám), přisuzuje mu i funkci vzdělávací, vidí roli rozhlasu v kultivování posluchače (také proto navrhuje střídat pořady určené všem s pořady „odbornými“). Nejvíce ji ovšem zajímá jeho funkce estetická. Věnuje tedy svou pozornost především rozhlasové umělecké

14 Viz (SRBOVÁ 1932a: 142-143). Některé soudy vyplývají samozřejmě z toho, že zvukový film je v tu dobu médium ještě velmi mladé, základní pozorování však obstojí i dnes.

15 Přehled její rozhlasové kariéry viz (JEŠUTOVÁ 2009: 37-38).

16 Především Co to je, když se řekne (Praha: Svoboda, 1968, poslední vydání 2008); Malá světová obrazárna (Praha: Svoboda, 1971).

17 Viz např. (SRBOVÁ 1934f: 84-85). Úvahu vysílal 10. 10. 1934 Československý rozhlas. 
produkci - samotnému slovu, rozhlasové hře (a rozhlasovým úpravám různých textů), prostoru v rozhlasové hře, podstatě rozhlasového herectví (a způsobu, kterým formuje herectví a stává se vedle filmu nezbytnou pomůckou při výuce herectví) a rozhlasové režie. Odhaluje přitom mimochodem, jak jsou všichni rozhlasoví pracovníci současně objeviteli i budovateli tradice, jak mnohé vzniká „z technického nedostat$\mathrm{ku}$ " a improvizace.

Běžný dobový diskurs přesahuje uvažování Olgy Srbové o onom „imaginárním“ prostoru rozhlasové hry, v němž nevidí spojitost $\mathrm{s}$ divadlem, ale spíše s literaturou, totiž se zapojením fantazie. Jestliže divák na jevišti vidí kulisy, které mu představují les (a stále ví, že je to jen dekorace), při poslechu rozhlasu (stejně jako při četbě románu) si posluchač „nepředstavuje plátno a barvy, nýbrž les skutečný, nejde už o systém jevištních znaků, nýbrž o reálnou podobu“ (SRBOVÁ 1941: 18). Divák se stává přímým účastníkem děje a rozhlasová iluze je silnější než iluze divadelní, literární, ba i filmová. Proto mohli Američané při poslechu hry o vpádu Martanů uvěřit, že jsou Spojené státy napadeny, proto se čeští posluchači domnívali při poslechu hry Požár v opeře, že Národní divadlo zase hoříi. ${ }^{18}$

Rozhlas také bez problémů zvládá kromě dialogu a monologu i vnitřní dialog, nedělá mu potíže vést děje simultánně, prolínat různé děje, které mohou být reálné i snové a mohou se odehrávat stejně na různých koncích světa i v lidském nitru. Mnoho malých poznámek svou dobu předešlo: To když Olga Srbová uvažuje o různém postavení recipienta divadla a koncertu ve veřejném prostranství, kdy je členem kolektivu na rozdíl od osamělého posluchače u rozhlasového přijímače; naznačuje i problém pasivity a aktivity recipienta, což jsou jevy, které bude mediální věda rozvíjet daleko později. Recenzent ve Slově a slovesnosti považuje její úvahy za velmi podnětné a jen lituje, že se jinými rozhlasovými útvary (rozhlasová přednáška, povídka, recitace) nezabývá podrobněji. Pravda je, že na taková témata došlo teoreticky i prakticky až v době, kdy se stala zaměstnancem Československého rozhlasu a kdy se snažila realizovat svou vizi rozhlasového vysílání pracujícího svými specifickými rozhlasovými prostředky. ${ }^{19}$

18 Slavná Wellsova Válka světů byla vysílána 30. 10. 1938. Již osm let předtím realizoval Československý rozhlas Grmelovu katastrofickou rozhlasovou hru Požár v opeře, která rovněž posluchače vzrušila tak, že někteří Pražané se vydali zkoumat, zda stoupá dým z hořícího Národního divadla.

19 Tu vyjádřila v kritickém článku „Zrcadlo našich dnů - Úkoly československého rozhlasu“ (Cil 1 (1945): 3: 47). Tehdy s ní polemizovala Anna Hostomská svým pojednáním „Z rozhlasu o rozhlase“ (Cil 2 (1946): 1: 13-14), jejíz poněkud profesně ubližzená reakce prozrazuje, že hledání specifiky rozhlasové práce bylo ještě v plenkách. 
Do roku 1946 byla nejspíše Olga Srbová známá širší veřejnosti především jako divadelní kritička. ${ }^{20}$ Svou kariéru začala v proslulém Studentském časopise. ${ }^{21}$ Tiskla zde od roku 1927 nejprve své první básně a povídky a velmi záhy (už od roku 1930) také úvahy o divadle a divadelní kritiky. Publikovala samozřejmě i jinde, ${ }^{22}$ především v Útoku, čtrnáctideníku pro kulturu, politiku a hospodářství (vycházel v letech 1930-1938), kam spolu s ní psal o divadle také Jaroslav Jan Paulík a Josef Träger. Publikovala i v Listech pro kritiku a umění, redigovaných Bedřichem Fučíkem, Literárních novinách, Českém slově, Národni práci aj. Po osvobození se pak se stala recenzentkou Práce, kde se její kritický talent naplno rozvinul. V její tvorbě vnímáme od počátku mnoho elánu, polemičnosti a útočnosti, ale mýlil by se, kdo by se domníval, že to je plod jakési mladistvé nerozvážnosti a nedostatku znalosti širších souvislostí. Právě naopak, publikované texty překvapují svou zralostí, hlubokým vhledem do divadelní problematiky, nesmlouvavým úsudkem, který nikoho nešetří - ani oblíbená divadla, ${ }^{23}$ ani vlastní generaci. ${ }^{24}$ Olga Srbová sledovala divadlo v celé jeho šíri, byla schopna ve svých osmnácti, dvaceti letech podávat kvalifikované rozbory jednotlivých inscenací i přehledy celé sezóny nebo výhledy do plánů divadel. Zajímala ji

20 Stranou ponecháváme její prózy, z nichž především Co nebylo v tř́dni knize (1943) získala velkou pozornost. Byla sice nejprve vnímána jako vedlejší plod pedagogické kariéry Olgy Srbové na pozadí tehdejších dívčích románků, ale dočkala se velkého kritického ohlasu (v pozůstalosti nacházíme 10 recenzí). Ve skutečnosti je tento text, označovaný jako román v románu nebo novela s velmi složitou a rafinovanou kompozicí, velmi blízký k experimentům, které ve stejné době používala Milada Součková, starší, ale blízká př́itelkyně Olgy Srbové. Viz (BRABEC 1995: 475), který Srbovou řadí mezi takové spisovatele jako František Kupka, Jaroslav Havlíček, Jaromír John atd., v jejichž povídkových souborech se projevila tendence stylizovat povídky jako „promluvy určitého typu vypravěče, charakterizovaného př́ímo autorským komentářem nebo nepř́mo samotným vyprávěním.“

21 Znovu připomeňme, že toto významné periodikum vycházelo v letech 1922-1942. Historii časopisu zpracovala ve své diplomní práci Karolina Pátková (Historický ústav Jihočeské univerzity v Českých Budějovicích, 1998).

22 Podle Mazáčové (2008) uveřejňovalo texty Olgy Spalové mezi lety 1931 a 1976 celkem na třicet různých periodik. Ani tento počet, jak se ukazuje, není konečný.

23 Kritický postoj k Emilu Františku Burianovi, který jsme naznačili, by si zasloužil samostatné pojednání. Ocitujme alespoň pasáž z článku „Divadelní sezóna vrcholí“ (1934b: 196-197), z níž je patrný autorčin vstř́ícný a nezaujatý postoj k divadelnímu dění: „Zajímavým pokusem je Burianova adaptace Molièrova Lakomce, která se nespokojuje vnější úpravou, nýbrž sahá až na dřeň samého děje. Harpagon dneška není jen zlým př́ízrakem svých dětí a sluhů; vládne světovým obchodem a jako můra vysává jeho kapitál světu možnost žít a volně dýchat. Elisa a Cleant jsou zpustlíci, kteří končí rukou proletářu La Fleche a Marianny. Je tu mnoho zajímavých a působivých scén, ale o jedno byl Molière ochuzen - z jeho lidí stala se známá schémata, z jeho dialogu zmizela všechna rafinovanost, $\mathrm{z}$ dramatu pevnost jeho stavby. To si uvědomíte při představení takového Tartuffa, kterého hrají na Vinohradech v prosté výpravě tří holých zdí (a tří záhadných lustrů na stropě). Co umění a dokonalé řemeslnosti v nejlepším slova smyslu je v každém dialogu, který se zauzluje a rozmotává, v kterém se odrážejí nejvnitřnější stavy jednajících osob a všechny dobré i špatné stránky doby! Tartuffe je prohlédnut a lapen, to je skromný obsah didaktické hry pro ty, kteří snadno sednou na lep svatouškům. Všechno napětí a úzkosti vám dávají zapomenout datum díla, které trvá, i když jeho tendence stárne.“

24 „Mezi dnešním a devětsiláckým mládím zeje propast. Všichni si uvykli divácké a glosátorské póze a přílišná kritičnost jim nedovolí přiložit ruce $\mathrm{k}$ dílu. Hodí žert nebo citát a utekou vám. Snad je vina stř̌edoškolská výchova, která nás učí pasivnosti a podrobení lhostejným autoritám, snad válka. Ale jsme takoví." (SRBOVÁ 1933a: 6-7) 
stejná témata jako J. Mukařovského, E. F. Buriana i J. Frejku, zabývala se dramatem, a to novým českým dramatem i adaptacemi, ${ }^{25}$ jevištní řečí a recitací, ${ }^{26}$ postavou a úlohou režiséra, ${ }^{27}$ scénografií, ${ }^{28}$ scénickou hudbou, ${ }^{29}$ výchovou herců, ${ }^{30}$ divadelní literaturou. ${ }^{31}$ Tam, kde měla k dispozici více prostoru, byla schopna podat výborné panorama soudobé české režie nebo nastínit problémy soudobé činohry a scénografie. ${ }^{32}$

Olze Srbové je jasné, že „divadlo je jediným uměním, kde publikum spolutvoří dílo“ (SRBOVÁ 1934e: 139-140), a právě proto vnímá velmi ostře všechny funkce divadla:

Říká se, že divadlo vychovává a povznáší, nebo se to němě předpokládá. Je to přirozená věc, že zjev, jemuž denně asistuje pár tisíc lidí, na ně nějak působí; jinak by tam patrně ti lidé nešli. Jde jen o to, v jakém smyslu vykonává divadlo vliv a k čemu vychovává. [...] Naučit lidi rozeznávat vkus a nevkus v provedení, je zároveň cestou k rozeznání dobré a špatné myšlenky, protože v obojím jde především o jedno - o rozeznávání pravdy a lži. Jestliže divadla nás zavalují balastem lživých myšlenek, nejsou to ona, která nás budou vychovávat k lepšímu chápání uměleckého díla. ${ }^{33}$ (S. A. 1935: 146)

Citát dobře dokumentuje postoj mladé autorky, která se nebojí ostře formulovat své soudy a má k dispozici široké znalosti divadelního kontextu i teoretické nástroje, třebaže je otevřeně neproklamuje.

Po roce 1945 se Srbová stává divadelní referentkou deníku Práce, její texty jsou zprvu ještě plny optimismu. Ve chvíli, kdy divadla po šesti letech vstupují do první svobodné sezóny, čteme tu ještě nadějný výhled do budoucnosti: Divadla, která nejsou už v rukou obchodních podnikatelů, budou veřejnými ústavy, brány světa jsou otevřeny, divadlo se smí hlásit ke klasikům svým i cizím, smí se zapojit do nejsoučasnější evropské dramaturgie, jevištní poezie už není zvrhlým uměním a „scéna se stává ze zglajchšaltované služky

25 Viz (SRBOVÁ 1932b: 228; SRBOVÁ 1934c: 225-226; S. A. 1933: 201-202; SRBOVÁ 1935b: 409; SRBOVÁ 1935c: 623-624).

26 Viz (SRBOVÁ 1933d: 266; SRBOVÁ 1935d: 167).

27 Viz (SRBOVÁ 1935e: 250-251). Velkou pozornost věnuje osobě K. H. Hilara a samozřejmě mladým režisérům (SRBOVÁ 1936: 118-119), po válce si velmi cení J. Pleskota.

28 Zajímavé a velmi instruktivní, byt velmi krátké, jsou její popisy scénografie Tröstrovy viz „Nový Sen noci svatojánské“ (SRBOVÁ 1946a: 4); „Irská balada“ (SRBOVÁ 1946b: 4); „Do třetice Shaw“ (SRBOVÁ 1946e) a Muzikovy viz např. „K Honzlově inscenaci Pražského žida“ (SRBOVÁ 1946d: 3).

29 Hudbě se věnuje téměř vždy, i když rozsah kritiky umožňuje jen paušální sdělení, občas velmi briskní viz např. „Čechovův Racek“ (SRBOVÁ 1946i): „scénickou hudbu obstarala vedlejší vinárna“; „Drama vzbouřené vsi“ (SRBOVÁ 1945b: 3): „Zelinkova hudba je snad sama o sobě dobrá, ale je jí užito jako v českém filmu - když se řekne slovo ,láska', rozšveholí se housle“. Má však za to, že scénické hudbě by se měla věnovat hudební kritika, viz např. „Matěj Kopecký v rozhlase“ (SRBOVÁ 1946f: 3).

30 Viz (SRBOVÁ 1942b: 307-308).

31 Viz (O. S. 1935: 8, O. S. 1940a: 108-111; O. S. 1940b: 110; SRBOVÁ 1940c; SRBOVÁ 1940b: 110).

32 Viz (SRBOVÁ 1937a: 118-119).

33 Zcela v dobovém kódu vidí autorka úkol výchovy v avantgardních scénách, lidovýchovných ústavech a dělnických kulturních organizacích. 
opět kolbištěm ducha“ (SRBOVÁ 1945a: 3). V provozu divadel se projevuje mnoho nového, mění se divadelní sít, ministr Nejedlý „zaručil divadlům a divadelním umělcům hmotné bezpečí, takže se mohou soustředit na své vlastní úkoly“ (SRBOVÁ 1945a: 3), všichni jsou plni dobré vůle „k znovuvybudování českého moderního divadelnictví v svobodném duchu“ (SRBOVÁ 1945a: 3). I jindy poměrně skeptická kritička zkrátka propadá porevolučnímu nadšení a očekává, že národní umělec budoucnosti „bude dělníkem ducha, budovatelem lepšího uměleckého i lidského zítřku“ (SRBOVÁ 1945a: 3). Nadšeně vítá hostující anglické divadlo v naději, že „naše jeviště se otevírá světu, který, doufejme, se otevírá také divadlu našemu“ (SRBOVÁ 1946g: 5), a jako mnozí jiní s jistou pýchou konstatuje, že „pohostinské hry londýnského divadla nám ukazují, jak jsme pokročili a předběhli valnou část Evropy v režijních a scénických výbojích“ (SRBOVÁ 1946h: 5). Předčasné ukončení kritické vlastní činnosti nám nedává možnost sledovat, jak by se byla Olga Srbová vyrovnala s dalším vývojem.

Skutečnost, že kritika má v deníku své značně limitované místo, nutí autorku velmi se koncentrovat na podstatná zjištění. Postupně si pochopitelně vytváří jakýsi ustálený způsob, jak inscenace prezentovat. Většinou podá chytře, poučeně a nebanálně informace o hře v širším kontextu, informuje o režii, výtvarné stránce (i tady zkoumá funkčnost scénografie), popíše velmi stroze, ale přesně herecké výkony a nakonec (zvláště tehdy, rozchází-li se její úsudek s úsudkem publika) se ráda zmíní o reakcích obecenstva. Občas neodolá a přidá jemný vtip určený chytrému čtenáři. ${ }^{34}$ Má vždy v paměti celou kariéru režiséra i předešlé inscenace každé hry, takže neváhá srovnávat, třebaže ví, že je to někdy pro současnou inscenaci nevýhodné.

Velmi zajímavé jsou její neúplatné recenze nových inscenací v divadle E. F. Buriana. ${ }^{35}$ Na rozdíl od předchozí kritické činnosti je tu více prostoru věnováno hercům, kteří jak je vidět v celé kariéře Olgy Srbové - zajímají autorku ze všeho nejvíce. Už její první „divadelní“ článek ve Studentském časopise (to je jí šestnáct let!), se jmenuje „Herec“ a pojednává o Eduardu Kohoutovi, Evě Vrchlické, Bedřichu Karenovi, Václavu Vydrovi a Jarmile Horákové a podává jejich hutné a přesné portréty (SRBOVÁ 1931: 262-263). Recenzentka neváhá sledovat herce, kteř́i ji zaujali, v pražských i mimopražských divadlech (SRBOVÁ 1939: 7). ${ }^{36}$ Její divadelní autopsie je překvapivě bohatá a obdivuhodná je i její pamět, která jí umožňuje i po letech ohromit znalostí detailu. I na nepatrné ploše je s to podat nutné informace i plastický portrét.

$\mathrm{V}$ časopiseckých recenzích však nikdy není dost místa na rozbor hereckého stylu. Skutečný prostor Olze Srbové vlastně poskytl až Československý rozhlas, v němž realizovala své herecké portréty doplňované zvukovými záznamy. Zachované texty k šestidílnému

34 Uznalou recenzi Višñového sadu v Divadle na Vinohradech (O. S. 1946: 4) končí: „Mnoho by se ještě chtělo říci, do široka promluviti, ale místa není.“

35 Jsou tu snad nejtvrdší slova adresovaná milovanému Burianovi: „Burian se octl nezaslouženě ve svízelné situaci: od dob D 34 nalezl tolik epigonů, že bychom toužili, aby nebyl nejlepším z nich." (SRBOVÁ 1946c: 3)

36 Sleduje např́ílad Miladu Matysovou, která po nadějných začátcích odešla z Prahy a hrála mj. Julii v Olomouci. Později ji Olga Srbová přivítá jako Anouilhovu Antigonu (SRBOVÁ 1946j: 7). 
cyklu Jiři Frejka a jeho herci (Jarmila Horáková, Jiřina Šejbalová, Jaroslava Adamová, Ladislav Pešek a Eduard Kohout) z roku 1968, stejně jako portréty Míly Pačové a Růženy Naskové svědčí o mistrovském zvládnutí analýzy hereckého projevu, této zřejmě nejtěžší teatrologické discipliny. Vždyt i Jan Mukařovský již v roce 1931 píše: „Je dost riskantní užití metody strukturálního rozboru pro umění herecké.“ (MUKAŘOVSKÝ 1966: 184) Olga Srbová jistě sdílela i myšlenky, které vyjádřil ve své přednášce přednesené v Pražském lingvistickém kroužku 24. 3. 1941. Stačí v závěrečném shrnutí problematiky zaměnit slovo básnik za širší pojem umělec:

\begin{abstract}
Pojetí [...] nechápe básnickou osobnost ani jako výsledek vlivů z vnějška, ani jako jev svézákonitý, ale jako proměnlivý průsečík sil doléhajících ze všech stran a vstupujících ve vzájemné protiklady. Iniciativa básnické osobnosti záleží pak v tom, že tyto přečetné protiklady organizuje v jedinečnou sestavu (která daleko vždy není harmonií). Předpoklad aktivity osobnosti vůči silám, které na jedince ze všech stran doléhají, je v psychofyzickém ustrojení jedincově, jež samo o sobě není sice rovněž jedinečné, ale má schopnost stát se krystalizační osou jedinečného seskupení a vyrovnání sil. ${ }^{37}$
\end{abstract}

Nejdůležitějšími nástroji tu nepochybně jsou dokonalá znalost hercova vývoje a jeho techniky (a tu si Olga Srbová osvojuje a střádá už od svých 13 let), přesná pamět (tu nacházíme i v jejích nejkratších kritikách), hluboká znalost divadelního, společenského i historického kontextu (tu konec konců prokázala i ve velkolepém panoramatu českého divadla Sága rodu Budilova, vynikající tradiční historiografické práci, která zahrnuje celou stovku let, v níž ovšem onu zásadní strukturalistickou stopu nenacházíme), ${ }^{38}$ a skutečná empatie.

Nepochybným vrcholem těchto snah je monografie Divadlo aneb Snář sledující divadelní kariéru Eduarda Kohouta. ${ }^{39}$ Olga Spalová je v tiráži této knihy uvedena jen jako redaktorka, která „literárně spolupracovala, rejstř́k y a fotografickou př́ilohu sestavila“. Jediná, zato velmi poučená a citlivá kritika z pera Evžena Turnovského, poodhalila problematiku autorství této knihy: „Ve stručné poznámce v závěru knihy říká dr. Olga Spalová několika větami, jak byla Kohoutova kniha napsána a charakterizuje tu i svuoj podíl na jejím vzniku. Přes všechnu skromnost, s níž jsou tyto věty formulovány, z nich zřetelně vyplývá, že je tu třeba vlastně mluvit o spoluautorství.“ (TURNOVSKÝ 1976: 224 -226) ${ }^{40}$

To je ovšem řečeno velmi decentně s ohledem na oba údajné spolupracovníky. $\mathrm{V}$ divadelních kruzích ovšem bylo veřejným, ale nikdy nezveřejněným tajemstvím,

37 Viz (MUKAŘOVSKÝ 1966b: 152). Dalo by se samozřejmě uvažovat o tom, jak dalece byla O. Srbová seznámena s dílem Romana Jakobsona a samožrejmě i o vlivu Honzlových studií.

38 Viz (SPALOVÁ 1980). Toto dílo ve svém oponentském posudku z 1. 7.1976 vysoce hodnotil František Černý, který zdůraznil, že autorka musela podstoupit „velice pracnou a namáhavou archívní práci, již může docenit snad jen pouze divadelní historik“ (posudek uložen v autorčině pozůstalosti). Lehce polemická, ale zásadně kladná je i recenze Ljuby Klosové (1979: 2).

39 Viz (KOHOUT 1975).

40 Mazáčová (2008) zvolila formulaci: „literárně zpracovala Memoáry herce E. Kohouta“. 
že skutečným autorem je příslušná redaktorka. Olga Spalová, která si Turnovského kritiky velmi považovala, ${ }^{41}$ však veřejně o své práci na tomto titulu nikdy nemluvila. Když kniha dostala cenu Odeonu, stála Spalová v pozadí, ba oddaně „nahrávala“ svému milovanému příteli a potvrzovala jeho verzi vzájemné spolupráce. Ve svých zápiscích však se svou ironií a sebeironií situaci glosuje: „Čtu Divadlo aneb Snář, je to ale opravdu krásná kniha! Budu žít trvale pod jménem Kohout. ${ }^{42}$ Vidím, jak jsem pod jménem Kohout ovlivnila celé nové dějiny." ${ }^{33}$ Po Kohoutově smrti si 27. října 1976 zapsala:

[...] a ubližoval své podobě, jak jsem ji provždy vytvořila Divadlem aneb Snářem. Jsem štastna, že mě k tomu pozval a že jsem to mohla udělat, byl to můj vděk, poslední kytice z těch, které jsem mu kdysi kladla na práh. Věřím, že nezvadne - a asi to bude jediné, co zůstane i po mně. Tak se splnilo, co jsem napsala - dávno, dávno tomu - v Milovaném hlasu, kde jako 13letá ř́íám: Ještě to nevíšs, ale Tvůj život patří mně. ${ }^{44}$

O tom, že knihu „psala v duchu celý život - skoro“, ${ }^{45}$ se můžeme přesvědčit už na zmíněném portrétu Eduarda Kohouta z roku 1931 a také na krátkém textu Milovaný hlas, který Olga Spalová uveřejnila v roce 1947 (SRBOVÁ 1947) a ve kterém zřejmě zpracovala své rané básně a vzpomínky na herce, jehož sice nikde nejmenuje, ale jenž je - jak díky svému hlasu, tak díky svým rolím ${ }^{46}$ - lehce identifikovatelný. I v tomto př́ípadě se jedná samozřejmě o Eduarda Kohouta. Užití stejného citátu z Neveuxovy hry Julie aneb snár̆ ${ }^{47}$ dokonce předjímá budoucí název monografie o Eduardu Kohoutovi: Divadlo aneb Snář. K celoživotnímu platonickému vztahu Olgy Spalové musíme přičíst množství kritik věnovaných tomuto herci a inscenacím, v nichž hrál, veliký obdiv, jaký prosakuje vzpomínkami na Hilara, bohatou znalost divadelního dění i jeho pozlátka i odvrácené strany divadla. Kromě dobré orientace v kritické literatuře je tu patrná i schopnost navázat na své předchůdce (sama vzpomíná na první pokus o Kohoutův životopis z pera Emanuela Jánského, oceňuje i studie Josefa Trägera a Miroslava Rutteho, je však jasné, že se stejně tak poučila u jiných kritiků, zejména u Jindřicha Vodáka). V této její práci vnímáme také pečlivé nakládání s archivním materiálem (o pár let později jej vrchovatě projeví právě v knize o dynastii Budilů). Je jasné, že si Kohout nemohl přát lepšího životopisce. Olga Spalová byla ostatně také autorkou námětu a spoluautorkou scénáře

41 Poznámka v diáři 16. 2. 1976: „Od Turnovského překrásný ref. o Divadle aneb Snáři.“

42 Poznámka v diáři 4. 3. 1980.

43 Poznámka v diáři 9. 11. 1983.

44 Černý sešit v pozůstalosti.

45 Poznámka v diáři 16. 7. 1977.

46 Odkazy na Kohoutovy role: Mistr lodník (1926: Al. Arnoux, Huon z Bordeaux), Dionysos (1927: Euripides, Bacchantky), Alceste (1945: Molière, Misantrop), Lord Darlington (1947: Wilde, Vějir lady Windermeerové), Hamlet (1926: Shakespeare, Hamlet), Př́zrak (1934: Giraudoux, Isabella na rozcestí), Orestes (1943: Goethe, Ifigenie na Tauridě), Michal (1932: Neveux, Julie aneb Snář), Lelio (1941: Goldoni-Hlávka, Benátská maškaráda). Srov. (SPALOVÁ 1947: 24 a KOHOUT 1975: 137).

47 Srov. (SPALOVÁ 1947: 24 a KOHOUT 1975: 137). 
k televiznímu dokumentu Herecký kniže z Kampy, který byl natočen ke Kohoutovým osmdesátinám. ${ }^{48}$

Divadlo aneb Snář však není životopis, není to typická memoárová literatura, která bývá chronologicky uspořádaná a více či méně spolehlivě podává jistý vhled do soukromí známých osobností korunovaný tím, čemu se posměšně říkává „veselé historky z natáčení". Tyto paměti jsou strukturované jako drama v pěti dějstvích s prologem a epilogem a důsledně vedené jako monolog protagonisty, který vzpomíná na svůj život a svou divadelní dráhu. Autorka jej prezentuje v nejlepším možném světle, nikoli však jako mramorovou bustu, ale jako živého člověka, který má své lásky i nelásky, a i když komentuje svět kolem sebe s ironií, je to vždy ironie laskavá a noblesní. Decentně obchází Kohoutovo soukromí, decentně upozorní i na jeho statečné chování za války. Srbová dokázala udržet Kohoutovu autostylizaci, která je „tak pronikavá a tak důsledná, že nakonec splývá s realitou hercova života, maska se stává tváří a tvář maskou" (TURNOVSKÝ 1976: 224). Bylo by možné v př́ípadě této její práce použít i výrok Františka Krčmy: „Ty se vzácně skromně a nezištně čtenáři skryješ, aby zobrazovaný Tebou nenápadně, ale beze zbytku osvětlen ze všech stran, vypadal takový, jakým byl a jak na něho pohlížela jeho doba. “49 Autorka se vskutku nikdy neprosazuje, vlastně vystoupí jménem jen dvakrát, když nemůže zamlčet, že se jako Olga Srbová pohybovala ve stejné společnosti. ${ }^{50}$

Evžen Turnovský tuto knihu označil za umělecké dílo. Není to tvrzení přehnané. Dá se říci, že na konci své profesní kariéry dokázala Olga Spalová v tomto díle využít všechny své znalosti teatrologické - teoretické i historické a dokázala díky svému nespornému literárnímu talentu vytvořit na pozadí divadelního dění té doby skutečný portrét osobnosti. Jako by se tu po létech uskutečnil onen avantgardní sen o spojení vědce a tvůrce, tentokráte v jedné osobě.

48 Hraný 42minutový dokument Československé televize byl natočen v roce 1969, režie Svatopluk Studený, scénář Olga Spalová a Ota Popp, kamera Karel Prokeš.

49 František Krčma v soukromém dopise datovaném 23. 9. 1979, který je uložen v pozůstalosti, takto glosuje Ságu rodu Budilova.

50 Srov. (KOHOUT 1975: 151 a 152). Snad jen pasáž o kritice za okupace, která je vložena do úst protagonistovi, prozrazuje trochu postoj autorky: „Herec mohl dosud hrát, ale kritikům se špatně psalo. Vodák byl mrtev a ti nejlepší odkládali pero jeden za druhým. Dosud psalo pár odborníků, psali i noví lidé, byli jsme chváleni, ale v obavě někomu neublížit nebo neublí̌zit sobě se často vytrácel ostrý kriticismus..." (KOHOUT 1975: 169). 


\section{Bibliografie}

BAUER, Michal. 2003. Ideologie a pamět' [Ideology and Memory]. Jinočany: H + H, 2003.

BOKOVÁ, Marie. 1999. Václav Voska. Praha: Achát, 1999.

BRABEC, Jiří. 1995. Česká literatura v letech 1939-1945 [Czech Literature Between 1939 and 1945]. In Dějiny české literatury IV. [History of the Czech Literature IV.]. Praha: Academia, 1995.

ČERMÁK, Petr, Claudio POETA a Jan ČERMÁK. 2012. Pražský lingvistický kroužek v dokumentech [Prague Lingvistic Circle in Documents]. Praha: Academia, 2012.

HONZL, Jindřich. 1939. Herecká postava [The Dramatic Character]. Slovo a slovesnost 5 (1939) 5: 239-245.

HOSTOMSKÁ, Anna. 1946. Z rozhlasu o rozhlase [In the Radio about the Radio]. Cil 2 (1946): 1: $13-14$.

JANOUŠEK, Pavel a kol. 2007. Dějiny české literatury 1945-1989 [History of the Czech Literature Between 1945 and 1989]. Praha: Academia, 2007.

JEŠUTOVÁ, Eva. 2009. PhDr. Olga Spalová (roz. Srbová) [Doctor Olga Spalová (née Srbová)]. Svět rozhlasu (2009): 22: 37-38.

KOHOUT, Eduard. 1975. Divadlo aneb Snár [Theatre or the Dream Book]. Praha: Odeon, 1975.

KLOSOVÁ, Ljuba. 1979. Kolárovská kletba? [Cursed by Kolár?]. Scéna (1979): 2: 2.

Mts. [MATHESIUS, Vilém.] 1941. Rozhlas a slovesnost [Radio and Verbal Art]. Slovo a slovesnost 7 (1941): 2: 106.

MAZÁČOVÁ, Stanislava. 2008. Heslo Olga Srbová-Spalová [Entry „Olga Srbová-Spalová]. In Lexikon české literatury, díl 1. [Lexicon of the Czech Literature, vol. 1]. Praha: Academia, 2008: 315-316.

MUKAŘOVSKÝ, Jan. 1966. Pokus o strukturní rozbor hereckého zjevu (Chaplin ve Světlech velkoměsta) [Chaplin in City Lights: An Attempt at a Structural Analysis of an Acting Phenomenon]. In id. Studie z estetiky [Essays on the Aesthetics]. Praha: Odeon, 1966: 184-187.

MUKǍ̌OVSKÝ, Jan. 1966b. Básník [A Poet]. In id. Studie z estetiky [Essays on the Aesthetics]. Praha: Odeon, 1966: 144-152.

NEZVAL, Vítězslav. 1981. Depeše z konce tisícileti [Dispatch from the End of Millenium]. Praha: Československý spisovatel, 1981: 580.

O. S. [SRBOVÁ, Olga.] 1935. Z divadelní literatury [Notes on Books about Theatre]. Literárni noviny 7 (1935): 13: 8.

O. S. [SRBOVÁ, Olga.] 1940a. Divadlo. Z divadelní teorie [Theatre. Notes on Theatre Theory]. Naše doba 48 (1940): 2: 108-111.

O. S. [SRBOVÁ, Olga.] 1940b. Klára Pražáková. Od včerejška k zítřku [Klára Pražáková: From Yesterday towards Tommorrow]. Naše doba 48 (1940): 2: 110.

O. S. [SRBOVÁ, Olga.] 1946. Višňový sad [The Cherry Orchard]. Práce (18. 4. 1946): 4.

PÁTKOVÁ, Karolína. Studentský časopis 1922-1942. Dostupné z: http://www.ff.jcu.cz/patkovakarolina. [cit. 2015-09-15].

RAMBOUSEK, Jiří. 2011. Jiřri Voskovec a Studentský časopis [Jiř̌i Voskovec and the Students' Magazine]. Universitas (2011): 3-4 (https://journals.muni.cz/universitas/article/view/271/263). 
S. A. [SRBOVÁ, Olga.] 1933. Jevištní adaptace [Adaptation for Stage]. Útok 3 (1933): 20: 201-202.

S. A. [SRBOVÁ, Olga.] 1934. Dvě divadla mladých [Two Theatres of the Youth]. Útok 4 (1934) 3: 45-46.

S. A. [SRBOVÁ, Olga]. 1935. Výchova obecenstva a herců [Educating the Audience and the Actors]. Útok 4 (1935): 10: 146.

SLADKÝ, Pavel. 2002. Počátky rozhlasové teorie [The Beginnings of Radio Theory]. Svět rozhlasu 2002: 8: 64-65.

SPALOVÁ, Olga. 1968. Co to je, když se řekne [What Is It to Say]. Praha: Svoboda, 1968.

SPALOVÁ, Olga. 1971. Malá světová obrazárna [A Small World Gallery]. Praha: Svoboda, 1971.

SPALOVÁ, Olga. 1980. Sága rodu Budilova. Sto let čského divadla na jevišti i v zákulisi [The Budil

Saga. One Hundred Years of Czech Theatre on the Stage and Backstage]. Praha: Odeon, 1980.

SRBA, Bořivoj. 2004. Řeč světla [The Language of the Light]. Brno: DiFa JAMU, 2004.

SRBOVÁ, Olga. 1931. Herec [The Actor]. Studentský časopis 9 (1931): 9: 262-263.

SRBOVÁ, Olga. 1932a. Divadlo a film [Theatre and Film]. Studentský časopis 11 (1932): 5: 142-143.

SRBOVÁ, Olga. 1932b. V. Nezval, Milenci z kiosku [V. Nezval: Lovers from Kiosk]. Studentský časopis 11 (1932): 8: 228.

SRBOVÁ, Olga. 1933a. Místo referátu [In Place of the Report]. Studentský časopis 13 (1933): 1: 6-7.

SRBOVÁ, Olga. 1933b. D 34 [Theatre D 34]. Studentský časopis 13 (1933): 2: 40-41.

SRBOVÁ, Olga. 1933c. Mladé divadlo [Theatre of the Youth]. Studentský časopis 13 (1933): 78-79.

SRBOVÁ, Olga. 1933d. O divadle a recitaci [On Theatre and Recitation]. Studentský časopis 12 (1933): 9: 266.

SRBOVÁ, Olga. 1934a. Děje se za jevištěm [What's Happening Behind the Stage]. Útok 3 (1934): 9: 266.

SRBOVÁ, Olga. 1934b. Divadelní sezóna vrcholí [Theatre Season Culminates]. Studentský časopis 13 (1934): 7: 196-197.

SRBOVÁ, Olga. 1934c. Domácí tvorba na divadle [Local Drama on the Stage]. Studentský časopis 13 (1934): 8: 225-226.

SRBOVÁ, Olga. 1934d. Osvobozené divadlo [The Liberated Theatre]. Útok 4 (1934) 6: 88-89.

SRBOVÁ, Olga. 1934e. Smrt divadelní avantgardy [The Death of Theatre Avant-Garde]. Listy pro uměni a kritiku 2 (1934): 16: 139-140.

SRBOVÁ, Olga. 1934f. Hovoří mladí [The Youth Is Speaking]. Studentský časopis 14 (1934): 3: 84-85.

SRBOVÁ, Olga. 1935a. D 35 [Theatre D 35]. Útok 4 (1935): 190-191.

SRBOVÁ, Olga. 1935b. Na okraj českého dramatu [On the Margine of Czech Drama]. Listy pro uměni a kritiku 3 (1935): 409.

SRBOVÁ, Olga. 1935c. O dramatizaci románů [Adapting Novel for the Stage]. Listy pro uměni a kritiku 3 (1935): 623-624.

SRBOVÁ, Olga. 1935d. O jevištní řeči [On the Stage Speech]. Studentský časopis 15 (1935): 5: 167.

SRBOVÁ, Olga. 1935e. Divadlo a režisér [Theatre and Director]. Studentský časopis 14 (1935): 9: 250-251.

SRBOVÁ, Olga. 1935f. Deset let divadelní avantgardy [Ten Years of Theatre Avant-Garde]. Studentský časopis 14 (1935): 10: 277-278. 
SRBOVÁ, Olga. 1936. Pražští divadelní režiséři [Prague Theatre Directors]. Útok V (1936): 12: 118-119.

SRBOVÁ, Olga. 1937a. Dějiny nového divadelnictví [History of the New Theatre]. Útok VI (1937): 10: $118-119$.

SRBOVÁ, Olga. 1937b. Deset let Osvobozených [Ten Years of the Liberated Theatre]. Studentský časopis 19 (1937): 9: 262-263.

SRBOVÁ, Olga. 1937c. Postava v novém dramatu [Character in the New Drama]. Slovo a slovesnost 3 (1937): 4: 221-226.

SRBOVÁ, Olga. 1937d. Scénické poznámky autorů [Authorial Stage Directions]. Život 15 (1937): 3-4: 98.

SRBOVÁ, Olga. 1939. Dopis herečce na venkov [A Letter to an Actress in the Country]. Eva (1939): 8: 7.

SRBOVÁ, Olga. 1940a. E. F. Burian. Pojd’te, lidé, na divadla s železnýma kladivama [E. F. Burian: Come, People, and Take Iron Hammers Against the Theatres]. Naše doba 48 (1940): 2: 108.

SRBOVÁ, Olga. 1940b. Česká žena na jevišti (Žena v českém umění dramatickém) [A Czech Woman on the Stage (Czech Female Playwrights)]. Naše doba 48 (1940): 2: 110.

SRBOVÁ, Olga. 1940c. Václav Vydra prosí o slovo [Václav Vydra Asks for a Word]. Př́loha Národni práce (26. 5. 1940).

SRBOVÁ, Olga. 1941. Rozhlas a slovesnost [The Radio and Verbal Art]. Praha: Vyšehrad, 1941. Edice Pro život, sv. 23 [For the Life series, vol. 23].

SRBOVÁ, Olga. 1942a. Na přelomu slohů [At the Turn of the Styles]. Život 17 (1942): 2: 120-121.

SRBOVÁ, Olga. 1942b. Otázka hereckého dorostu [The Students of Acting Issue]. Naše doba 49 (1942): 4: 307-308.

SRBOVÁ, Olga. 1945a. Do nové divadelní sezóny [At the Start of the New Theatre Season]. Práce (9. 9. 1945): 3.

SRBOVÁ, Olga. 1945b. Drama vzbouřené vsi [Drama of Revolting Village]. Práce (7. 10. 1945): 3.

SRBOVÁ, Olga. 1945c. Když kritik nechválí [When the Critic Does Not Praise]. Práce (8. 12.1945): 6.

SRBOVÁ, Olga. 1945d. Zrcadlo našich dnů - Úkoly československého rozhlasu [Mirror of Out Times: The Mission of the Czechoslovak National Broadcasting Company]. Cil 1 (1945): 3: 47.

SRBOVÁ, Olga. 1946a. Nový Sen noci svatojánské [New Midsummer Night's Dream]. Práce (15. 1. 1946): 4.

SRBOVÁ, Olga. 1946b. Irská balada [An Irish Ballad]. Práce (27. 1. 1946): 4.

SRBOVÁ, Olga. 1946c. Sentimentální Cyrano [A Pathetic Cyrano]. Práce (22. 2. 1946): 3.

SRBOVÁ, Olga. 1946d. K Honzlově inscenaci Pražského žida [Notes to Honzl's Production of the Prague Jew]. Práce (27. 2. 1946): 3.

SRBOVÁ, Olga. 1946e. Do třetice Shaw [Shaw for the Third Time]. Práce (15. 3. 1946): 3.

SRBOVÁ, Olga. 1946f. Matěj Kopecký v rozhlase [Matěj Kopecký on the Radio]. Práce (8. 8. 1946): 3.

SRBOVÁ, Olga. 1946g. Moderní Othello [A Modern Othello]. Práce (8. 10. 1946): 5.

SRBOVÁ, Olga. 1946h. Angličtí hosté na českém jevišti [English Guests on Czech Stage]. Práce (12. 10. 1946): 5.

SRBOVÁ, Olga. 1946i. Čechovův Racek [Chekhov's Seagull]. Práce (9. 11. 1946).

SRBOVÁ, Olga. 1946j. Antigona 42 [Antigone 42]. Práce (17. 11. 1946): 4. 
SRBOVÁ, Olga. 1947. Milovaný hlas [The Loved Voice]. Třebechovice: Dědourek, 1947.

STEHLÍKOVÁ, Eva. 2015. Malá zpráva o zmizení Olgy Srbové [A Small Note on the Disappearance of Olga Srbová]. In K. Hala a O. Vlčková (edd.). Ženy - divadlo - dějiny [Women, Theatre, History]. Univerzita Pardubice, 2015: 67-73.

TURNOVSKÝ, Evžen. 1976. Chvála vzpomínek [The Praise of Memories]. Program (1976): 224226.

\section{Summary}

\section{Structuralist Footprint of Olga Srbová}

The name of Olga Srbová (16. 7. 1914-14. 4. 1987) has almost fallen into oblivion, as she stopped to use her maiden surname after she entered into marriage with actor Jaromír Spal, being known as Olga Spalová since then. Therefore, she is mostly known for her later, post-war engagement in radio; but the first stop in her career, and her life's love, was theatre. Olga Srbová started her university studies in 1933, receiving Ph.D. degree from Czech and French Language and Literature at the Faculty of Arts, Charles University in 1937 (dissertation: "The Characteristics of the new Czech historical novel”). Among her teachers were, according to her student's record book, J. Mukařovský, A. Pražák, F. X. Šalda, M. Weingart, V. Tille and others.

Firstly, she thought of devoting herself to theatre theory; while only a few theoretical studies can be found in the scope of her works, they nevertheless testify that Srbová mastered the methods of her teachers with skill and understanding: "The Character in New Drama" (Word and Verbal Art 3 (1937): 4: 221-226) contributes to the changes of the concept of a character in the contemporary theatre; in the "Authorial Stage Directions" (Life 15 (1937): 3-4: 98) she explores the influence of the contemporary stage practice on the nature of stage directions. As many others of her generation she admired the new media - film and radio; to the latter she devoted a booklet Radio and Verbal Art (Praha: Vyšehrad, 1941), even now valued as one of the most important works of the time.

Until 1946 she wrote mostly theatre reviews, having started publishing in the renowned Students' Journal in 1927. There she published her first poems and short stories, and in a short time (from 1930 on) also essays on theatre and theatre reviews. She published in other periodicals too (in more than 30 between 1931 and 1976), the height of her career as a critic being the cooperation with the daily newspaper Práce (after 1945). Being well versed in the whole of the contemporary theatre, both Czech and European one, she could comment with equal expertise on drama, stage speech, verse speaking, character building, direction, set design, actors training, and theatre theory. However, the most interested she was in actors' work; the indisputable top of her attempts at portraying actor is the Theatre or the Book of Dreams (Praha: Odeon, 1975), the story of the actor's career of Eduard Kohout. 


\section{Klíčová slova}

strukturalismus, divadelní kritika, teorie divadla, teorie herecké tvorby, Eduard Kohout

\section{Keywords}

Structuralism, theatre criticism, theatre theory, theory of acting, Eduard Kohout

\section{DOI: 10.5817/TY2016-1-9}

Prof. PhDr. Eva Stehlíková (1941) - přednáší na FF MU v Brně (ČR), specializace: antické a raně středověké divadlo, novodobé inscenace antického dramatu, problematika intertextuality. Kontakt: stehlice@gmail.com.

Prof. PhDr. Eva Stehlíková (1941) has a position at the Department of Theatre Studies, Faculty of Arts, Masaryk University in Brno (Czech Republic). The fields of her scholarly interests include Classical and Early Medieval theatre, modern productions of Classical drama, and intertextuality. Email: stehlice@gmail.com. 


\section{Přiloha}

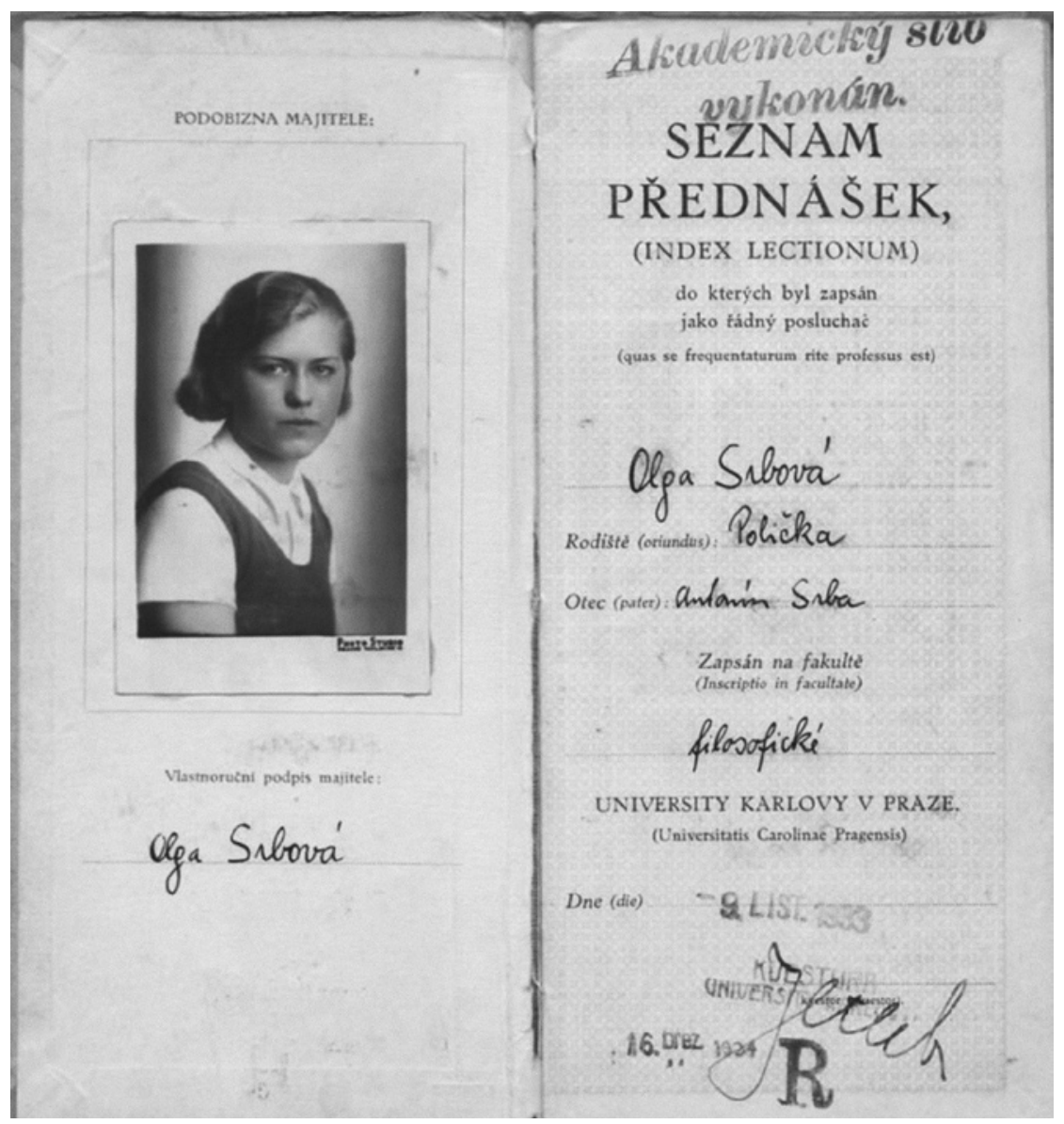

Index Olgy Srbové (Materiál z pozůstalosti Olgy Srbové-Spalové, v majetku dědiců) 


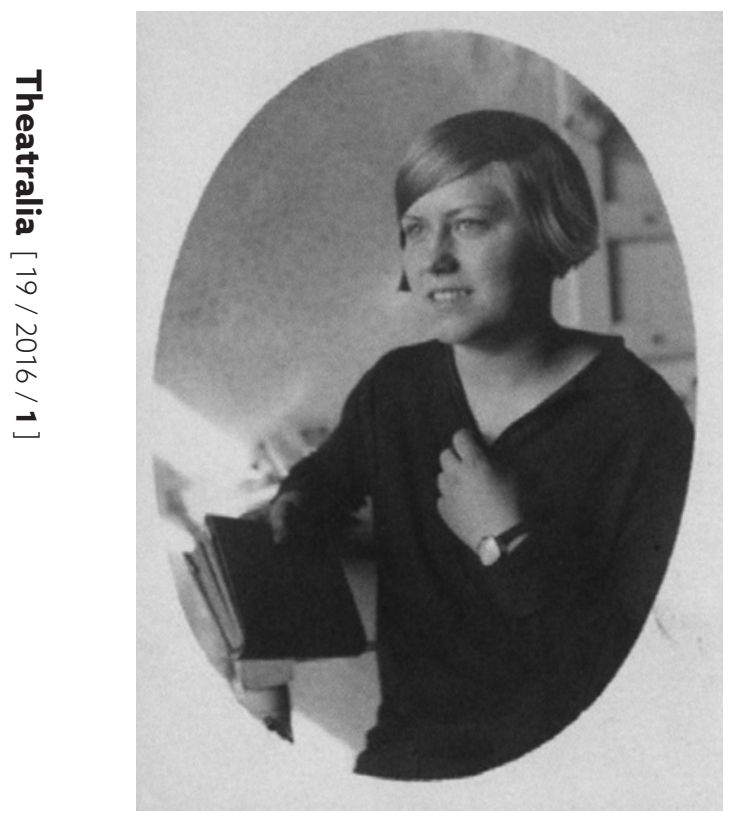

Olga Srbová v době studií

(Materiál z pozůstalosti Olgy

Srbové-Spalové, v majetku dědiců)

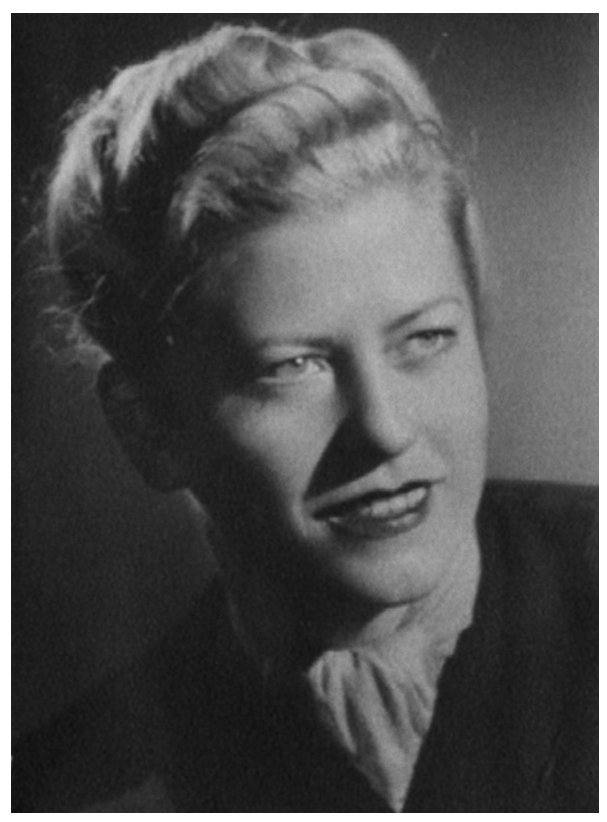

Olga Srbová ve čtyřicátých letech

(Materiál z pozůstalosti Olgy

Srbové-Spalové, v majetku dědiců) 


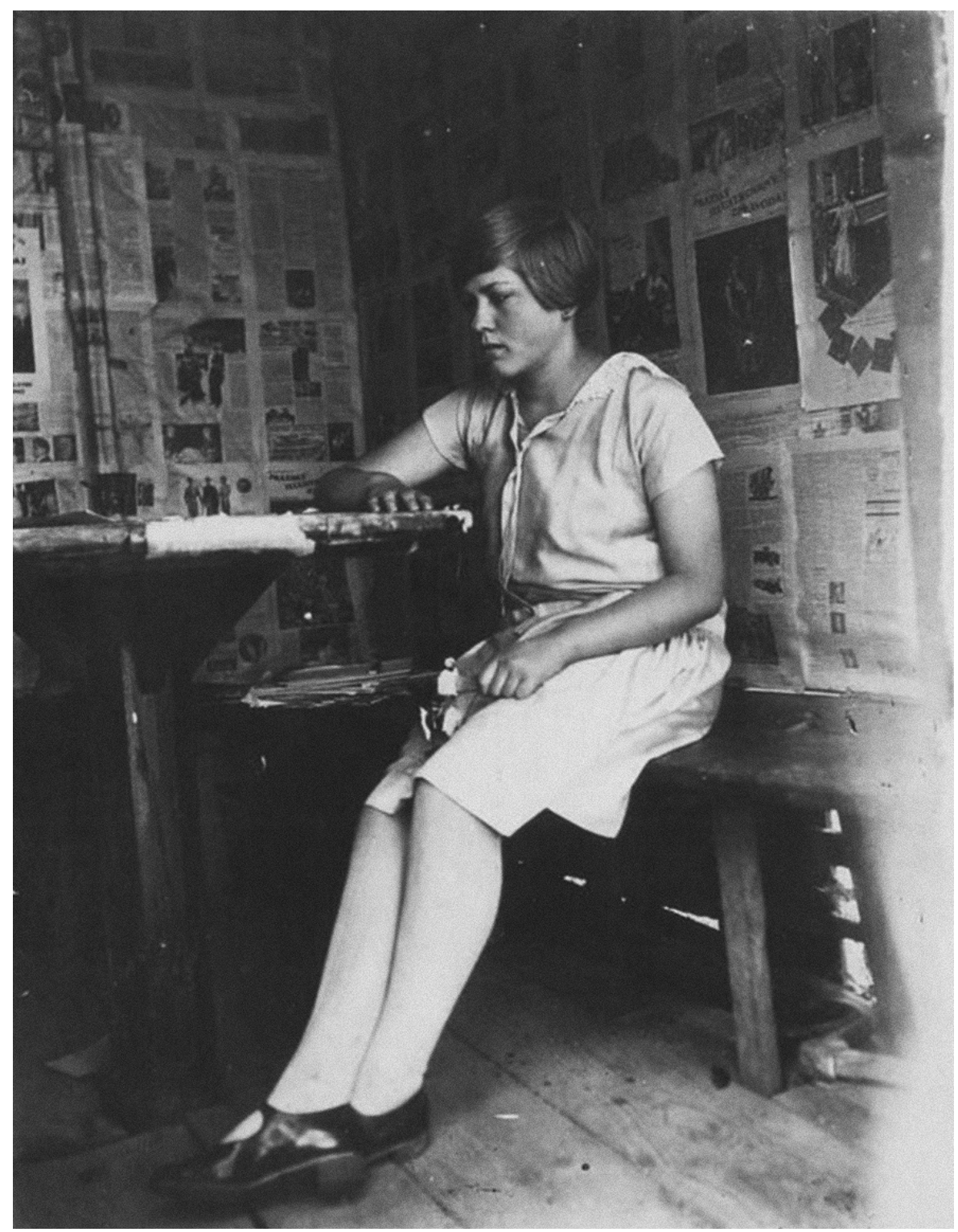

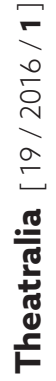

Olga Srbová na snímku z období dospívání

(Materiál z pozůstalosti Olgy Srbové-Spalové, v majetku dědiců) 